\title{
Boron/Calcium Deficiency causes Ginger Zingiber officinale Roscoe Diebackin Hawaii
}

\author{
Paul Reed Hepperly* and Francis Zee \\ University of Illinois at Urbana-Champaign, USA
}

Submission: July 06, 2016; Published: July 31, 2017

"Corresponding author: Paul Reed Hepperly, University of Illinois at Urbana-Champaign, USA, Email: paul.hepperly@gmail.com

\section{Opinion}

Currently, the big Island of Hawaii is the site of the vast majority of all Hawaiian ginger. The island is the youngest of the Hawaiian archipelago and is dominated by recently weathered volcanic materials or geologically young soils. The island is notably lacking in calcareous soil which would depend on present of coral reef materials that are rich in calcium. Volcanic soils can be rich in many minerals but they are not usually good calcium sources.

Conway et al. [1] conclusively showed the ability of calcium to lower issues with apple fruit can greatly reduce rotting from fungi. Calcium has also been implicated in a metabolic messenger system in plant defensive reactions. Defensive plant reactions were fostered when the calcium solution were infiltrated into the fruits. Optimized calcium reduced decay and extended storability. Similar work is also available in potatoes and other root crops.

Calcium in ginger and other plants is mobilized through the apoplastic system of xylem and the foliar application of Calcium may do little to remediate a calcium deficiency in the rhizome and root due to lack of robust mobility in phloem system of the plant Marschner [2]. As such the providing of adequate amounts of calcium would need to have the availability coming from the soil or the soil amendment ideally.

According to Shorrock [3] boron is the most common deficiency of micronutrients in all plants. often seen as a co factor for the stimulation of calcium movement and is structurally connected together is cellular walls and membranes. The lack of calcium and boron lead to lack of cellular wall and membrane integrity which results in increasing membrane leakage.

After the 1970's decline in the Hawaii sugarcane refining led to growing opportunities to produce commerical ginger due to increased availability of tillable land. The flourishing of the ginger production industry has been compromised by bacterial
Wilt Ralstonia solancearum which can lead to $90 \%$ ginger losses under epidemic conditions. With the overriding concern for phytosanitary issues ginger crop nutrition has received less consideration.

After working on our clean propagation system our efforts were led to optimize the Hawaiian crop by identifying potential nutrient constraints. Diverse production zones were analyzed by collecting samples of ginger leaflets 20 to 40 per site drying them and having them analyzed by atomic spectral analysis.

While the major nutrients NPK were within optimal ranges the micronutrient Boron was critically deficient as well as Calcium a secondary nutrient. In both Hamakua and Kona production zones the defiency of both boron and calcium was consistent.

In addition supplementing with Boron and Calcium that proved effective and economical in reducing the symptoms of deficiency and improved ginger root health and appearance.

Boron plays a key functional role in cell wall formation. This essential micronutrient is special in its narrow range between sufficiency and crop optimization and excess causing crop damage through toxicity. This concern has led to a widespread shunning of giving emphasis on optimization because of concerns related to potential toxicity.

Although needed in very small amount Boron is non mobile in the plant requiring continuous appropriate support to prevent acute deficiencies. In mineral soil the release of Boron is notably slow and organic matter reserves are needed to facilitate more rapid and continuous release. Many times the onset of Boron deficiencies is associated with the water availability issues of the mineral soil without sufficient soil organic matter content.

Boron is critical in cell permeability and cell wall/membrane leakage will result in apices of plant growth to their weaken 
and death. This can eliminate the normal apical dominance and side shoot proliferation leads to classic witch brooms. Both Calcium and Boron can be associated with presently identified tip blighting.

Halder et al. [4] working in Bangladesh identified a key role of Boron and Zinc in ginger production Optimizing Boron nutrition there led to increase of ginger root yields of 46 to $89 \%$ over non treated plots while 23 to $52.3 \%$ increases were found for Zinc optimization. In our studies boron was critically deficient but zinc was within optimum levels (Figure 1-3).

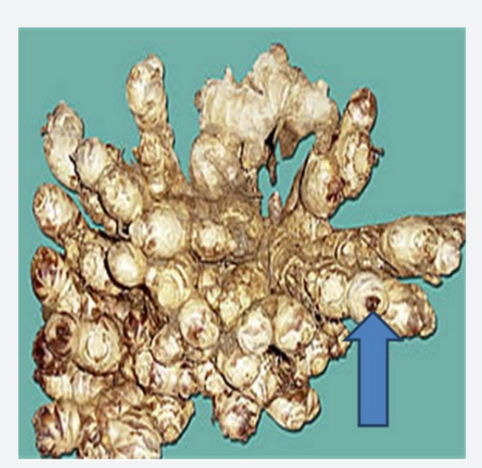

Figure 1: Note the upward pointing black arrow showing the classic boron/calcium deficiency symptomsof ginger root rhizomes apice die back. Boron/calcium content in Hawaii was notably low and soil and foliar supplementation eliminated the symptoms.

\section{Foliar Boron (ppm) in optimized Australian ginger as compared with Big Island Sites (2001-3)}

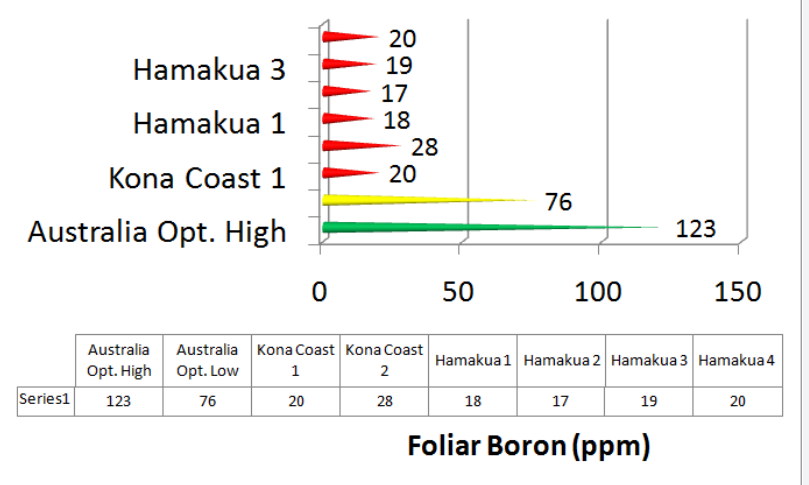

Figure 2: The yellow and green levels denote the low and high optimum levels of boron based on Australian work. The red levels indicate the deficiency foliar levels from farmer field samples in the 2 zones for producing ginger on the big island of Hawaii.

When addressing the phytosanitary issue of bacterial blight Hepperly et al. [5] developed a clean seed propagation system. In this effort we started with emphasizing a medium based on the native volcanic pumice material. This material was abandoned based on the gross nutrient imbalances related to its use. Of the major nutrient problems with the pumice is high rates of potassium and magnesium and its notably low level of calcium.

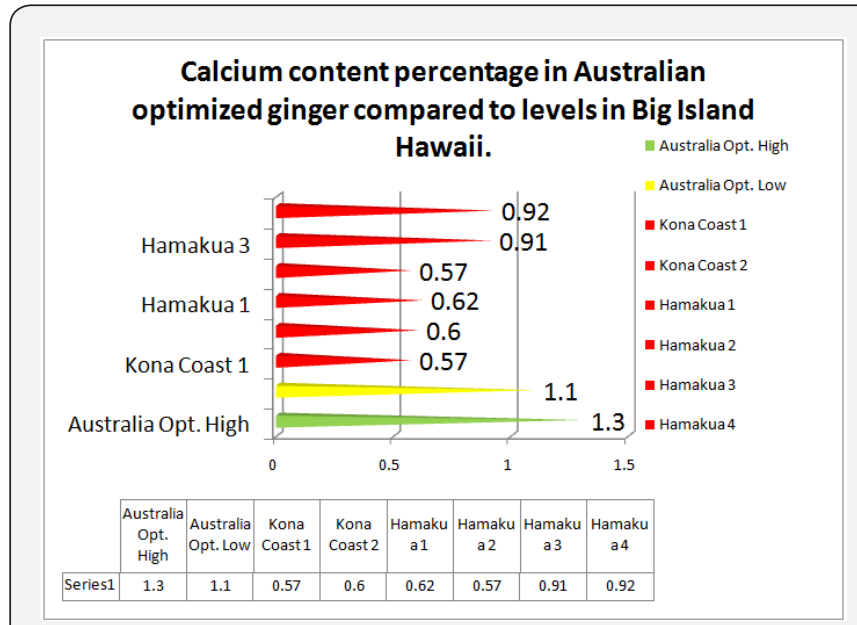

Figure 3: Percentage content of calcium in yellow and green levels, 1.1 to 1.3 percent representing the optimization as found from Australian literature. Note the Hawaiian levels do no reach optimized levels in any case.

Although we were successful in characterizing the bacterial wilt populations and pathogenic races and developing clean seed systems directed at bacterial wilt and also identified role of soft rot bacteria [6], we did less to identify which conditioned epidemic condition associated with the severe epidemic environment.

Work would indicate both soft rot and bacterial wilt has been shown to be influenced by calcium nutrition. While the development of clean productions is a good start the present studies identified deficiency of boron and calcium as widespread and limiting under Hawaii production environments [7,8].

In resolving our health issues in our agricultural system we need to address not just the pathogen construct or the environmental factors but also host nutrition. In terms of these nutritional aspects they have an advantage of greater ability to resolve them by relatively low cost inputs compared to housing production systems we have focused on.

The implications for prevailing boron calcium deficiencies need further work to develop the best methodologies to resolve them more efficiently.

\section{References}

1. Conway WS, Sams CE, Hickey KD (2001) Pre-and postharvest calcium treatment of apple fruit and its effect on quality. In International Symposium on Foliar Nutrition of Perennial Fruit Plants 594: 413-419.

2. Marschner H (1995) Functions of mineral nutrients: macronutrients. Mineral nutrition of higher plants 2: 379-396.

3. Shorrocks Victor M (1997) The occurrence and correction of boron deficiency. Plant and soil 193(1-2): 121-148.

4. Halder NK, Shill NC, Siddiky MA, Gomes R, Sarkar J (2007) Response of ginger to zinc and boron fertilization. Asian J Plant Sci 6(2): 394-398.

5. Paul H, Zee F, Kai R, Arakawa C, Meisner M, et al. (2004) Producing bacterial wilt-free ginger in greenhouse culture. Univ of Hawaii College Tropical Agriculture SCM-8, USA, p. 6. 
6. Nishijima KA, Alvarez AM, Hepperly PR, Shintaku MH, Keith LM, et al. (2004) Association of Enterobacter cloacae with rhizome rot of edible ginger in Hawaii. Plant Disease 88(12): 1318-1327.

7. Alvarez AM, Trotter KJ, Swafford MB, Berestecky JM, Yu Q, Ming R, et al. (2002) Characterization and detection of Ralstonia solanacearum strains causing bacterial wilt of ginger in Hawaii. In: Allen C, Prior P,
Hayward AC (Eds.), (3 $3^{\text {rd }}$ edn), The American Phytopathological Society, St. Paul, USA.

8. Yu Q Alvarez AM, Moore PH, Zee F, Kim MS, De Silva A, et al. (2003) Molecular diversity of Ralstonia solanacearum isolated from ginger in Hawaii. Phytopathology 93(9): 1124-1130.

\section{Your next submission with Juniper Publishers will reach you the below assets}

- Quality Editorial service

- Swift Peer Review

- Reprints availability

- E-prints Service

- Manuscript Podcast for convenient understanding

- Global attainment for your research

- Manuscript accessibility in different formats

( Pdf, E-pub, Full Text, Audio)

- Unceasing customer service

Track the below URL for one-step submission https://juniperpublishers.com/online-submission.php 